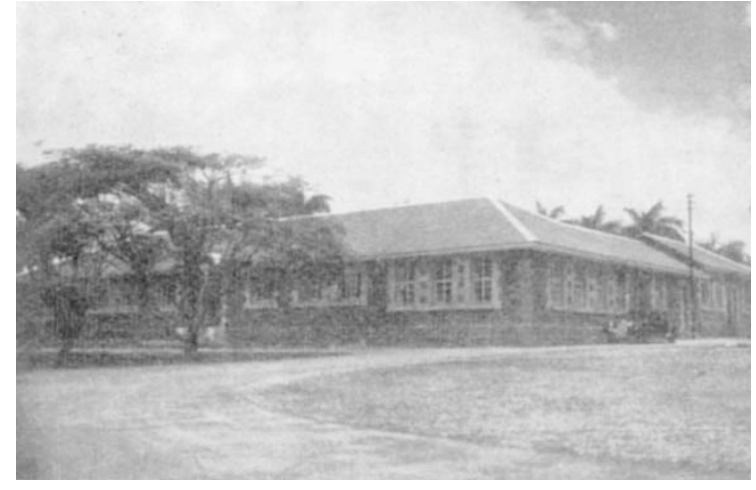

The new Sngurcane Research Station. Mauritius, showing part of the Entomological Dfvision and Departmental Library

In this work the Station achieved what was to prove an outstanding success by producing the variety known as $M 134 / 32$. By 1947 (the first year in the series of record crops) this remarkable general-purpose cane had replaced all other varieties to the extent of 80 per cent of the island's acreage in cane. Since then, more than 90 per cent of the cane area has been planted in $M 134 / 32$. The variety has not only come up to requirements in regard to yield capacity, sugar content and resistance to the major pests and diseases; it has also enabled an extension of the acreage in cane by reason of its greater tolerance of climatic variation. Other good canes have been produced by the Station; but they have been overshadowed by $M 134 / 32$, or they are adapted to special environmental conditions and are therefore grown only on a small scale. Indeed, it may be said that M134/32 has been embarrassingly successful for, though it still shows no sign of weakening, there is grave danger in relying on a single variety.

In some degree this success has also tended to overshadow other achievements of the Station, such as the very thorough investigation and survey of the soils of the cane belt made by the Chemical Division, and the work on foliar diagnosis. The latter, a method of determining the nutritional status of the cane plant from leaf analysis, is now applied on a commercial scale by a special laboratory financed from the Sugar Industry Reserve Fund. The work of the Division of Botany, too, has led to valuable improvements in field practice, notably in the pretreatment of cane setts now widely adopted, and the control of weeds by means of weed-killers. Many of the more noxious weeds of eane plantations can now be controlled by selective weed-killers, and several thousand acres of infested land have already been cleared by this means.

Research will bo no less necessary in the future to ensure efficiency of production in what may well be highly competitive conditions. Breeding work must go on, and one of the most urgent problems is to find successors for $M 134 / 32$. The most probable successor for the immediate future is another product of the Station, the variety $M 423 / 41$, which gives promise of successfully rivalling $M 134 / 32$ and of carrying the curve of sugar production to still higher levels. Other work which is in the initial stages includes investigation of the relation between root vigour and resistance to damage by Clemora Smithii, the most destructive pest of cane with which the Mauritian planter has to contend, examination of the role of certain inorganic fertilizers, especially lime and magnesia, the accumulation of data to enable foliar diagnosis to be extended to these elements, and further study of some weed species for which no satisfactory control has yet been found. The Division of Botany has recently engaged in an inquiry into the vexed question of the effects of interplanting food crops with cane.

The construction of a new building for the Mauritius Sugarcane Research Station, which was formally opened by the Governor early last year and in the midst of a minor cyclone, is an indication that the importance of future research is clearly recognized even in the phase of political re-organization through which the Colony is passing.

\section{BROWN TROUT RESEARCH IN SCOTLAND}

IN February 1948 a committee was appointed by the Secretary of State for Scotland "to supervise a programme of research into the factors affecting the number, size and growth of brown trout in Scottish waters of varying types and into measures for improving the stock". This research was proposed by the North of Scotland Hydroelectric Board and the Scottish Home Department, with the support of the Scottish Tourist Board. It aims at finding out how trout fisheries in Scotland can be improved and how trout stocks can be established and maintained in the reservoirs being constructed in various parts of the country for the development of hydro-electric power.

The research is carried out under the general supervision of a committee under the chairmanship of Prof. C. M. Yonge. The headquarters laboratory is at Faskally House, near Pitlochry, in Perthshire, and the work is directed by Mr. K. A. Pyefinch, who reports on the work for the first year in a new series of Scottish Home Department Scientific Investigation Reports, Freshwater and Salmon Fisheries Research, No. 1*. A comprehensive biological survey is being made of certain selected streams and lochs of the 700 square miles of catchment area lying along the Tummel Valley and stretching from Loch Laidon through Loch Rannoch to Pitlochry, and including the River Garry and its tributaries. This area includes a variety of different types of habitat, and it is evident that the investigations may throw new light on the reasons for the great variation in growth shown by trout in different waters. Biological investigations on the trout include the tagging of large numbers and a modern method of sampling fish populations in small streams by the use of electric currents for stunning fish within a length of stream. These researches are supplemented by seasonal observations on bottom fauna and on the plankton. Marked differences have been found in the composition of the zooplankton between the larger and smaller lochs.

Preliminary investigations have been made which will prove valuable for comparison in following the biological sequence which will develop over the area which has recently been inundated to form the new reservoir at Pitlochry.

F. S. RUSSELI

* Scottish Home Department. Scientific Investigations, Freshwater and Salmon Fisheries Kesearch, No. 1 : Report by the Supervisory Committee for Brown Trout Research, 1948-49. Pp. 12. (Edinburgh and London: H.M. Stationery Office, 1950.) 18. net. 